\title{
A exigência de proporcionalidade no controle abstrato de normas brasileiro
}

\author{
Elival da Silva Ramos \\ São Paulo, Brasil \\ eramos@sp.gov.br
}

Mestre, Doutor e Livre-Docente em Direito do Estado - Área de Direito Constitucional pela Faculdade de Direito da Universidade de São Paulo.

Professor Titular de

Direito Constitucional na

Faculdade de Direito da USP. Procurador do Estado de São Paulo.

Ex-Procurador Geral do Estado de São Paulo (2001/2005).

Recebimento do artigo: 18/11/2009 Aprovado em: 10/12/2009

\section{Resumo}

O controle de proporcionalidade dos atos legislativos, máxime em matéria de direitos fundamentais, vem assumindo importância crescente na jurisprudência do Supremo Tribunal Federal. Neste artigo, pretende-se contribuir para o adensamento teórico em torno da matéria, demonstrando a parcial coincidência entre os postulados normativos da proporcionalidade e da razoabilidade e apontando-se para categoria doutrinária que os substituiria com vantagem: a inconstitucionalidade finalística. Esta é concebida como uma quarta modalidade de vício de inconstitucionalidade, que se agregaria aos vícios formal, material e orgânico, tornando mais consistente e efetiva a atuação dos órgãos de controle.

\section{Palavras-chave}

Vício de Inconstitucionalidade de controle de constitucionalidade. Proporcionalidade. Razoabilidade. Discricionarieda de Legislativa. Supremo Tribunal Federal. 


\title{
The demand of proportionality in the abstract judicial review of Brazilians rules
}

\author{
Elival da Silva Ramos
}

\section{Abstract}

The proportionality control of legislatives acts, especially those regarding fundamentals rights, has had an increasing relevance in the Brazilian's Supreme Federal Court jurisprudence. This article aims to contribute to the theoretical reflection on the subject, showing the partial overlap between the normative assumptions of proportionality and reasonableness and pointing out to a doctrinaire category that would replace them with advantage: the purposeful unconstitutionality. This is designed as a fourth type of unconstitutionality, which would be added to the formal, material and organic categories, allowing control instances to rule the constitutionality control more consistently and effectively.

\section{Key words}

Unconstitutionality.Judicialreview.Proportionality. Reasonableness. Legislative discretion. Brazilian Supreme Federal Court.

* Comunicação apresentada na "XXVe Table Ronde Internationale de Justice Constitutionnelle", realizada em Aix-en-Provence, França, no período de 4 a 5 de setembro de 2009, pelo Instituto "Louis Favoreu" - "Groupe d'Etudes et de Recherches sur la Justice Constitutionnelle GERJC", da Universidade "Paul Cézanne" - Aix-Marseille III. 


\section{Sumário}

Inconstitucionalidade finalística e proporcionalidade.

I A natureza da exigência de proporcionalidade.

II Proporcionalidade e razoabilidade.

III Elementos do requisito de proporcionalidade e "teste de proporcionalidade".

IV A intensidade do controle de proporcionalidade.

V Discricionariedade legislativa e controle de proporcionalidade.

VI O controle de proporcionalidade na jurisprudência do Supremo Tribunal Federal.

VII Avaliação prospectiva.

\section{Inconstitucionalidade finalística e proporcionalidade}

Desde os primeiros estudos sistemáticos sobre jurisdição constitucional, foram identificadas duas espécies de incompatibilidade entre atos legislativos subalternos e Constituição, correspondentes aos vícios de inconstitucionalidade formal e material. O primeiro consistente na inobservância das normas constitucionais sobre processo legislativo e, o segundo, na discrepância entre o conteúdo da lei e determinadas prescrições constitucionais aplicáveis à matéria regulada em nível ordinário. ${ }^{1}$

Nos Estados federais, outra modalidade de vício de inconstitucionalidade veio, posteriormente, a obter autonomia no plano doutrinário: a inconstitucionalidade orgânica, caracterizada pela violação das regras da Constituição que cuidam do rateio da competência legislativa entre os diversos níveis territoriais de poder.

Esta é a lição de Kelsen, em sua célebre exposição, de 1928, sobre "A garantia jurisdicional da Constituição": "A Constituição não é, então, unicamente uma regra de procedimento, mas também uma regra de fundo; por conseguinte, uma lei pode ser, então, inconstitucional, seja por causa de uma irregularidade de procedimento em sua elaboração, seja em decorrência da contrariedade de seu conteúdo aos princípios ou diretivas formulados na Constituição, quando excede os limites estabelecidos por esta. Por isso costuma-se distinguir a inconstitucionalidade formal da inconstitucionalidade material das leis." In: Jurisdição constitucional. Introd. Sérgio Sérvulo da Cunha. Trad. Alexandre Krug, Eduardo Brandão e Maria Ermantina Galvão. São Paulo: Martins Fontes, 2003, p. 132. 
As Constituições social-democráticas, dominantes a partir das primeiras décadas do século passado, suscitaram novas questões no âmbito da teoria da inconstitucionalidade, quer tornando mais complexa a inconstitucionalidade por ação, quer fazendo vir à tona o problema da omissão inconstitucional. ${ }^{2} \mathrm{Na}$ medida em que o Estado já não mais se ocupa da mera proteção do status libertatis, dele se exigindo papel ativo na construção de uma sociedade mais justa e igualitária, a demora na adoção das providências de ordem legislativa exigidas para a implementação do programa constitucional passa a constituir um grave problema, cuja solução, todavia, parece ultrapassar as forças da jurisdição constitucional. ${ }^{3}$ Contudo, perspectiva bem mais promissora adveio da intensificação do exame da conformação do ato legislativo aos fins traçados pela Constituição, o que permitiu aos órgãos de controle perceber que nem sempre o descompasso entre aquele e esta se acomoda, satisfatoriamente, nas categorias de vício anteriormente apontadas.

A prática do controle de constitucionalidade nas últimas décadas e a sistematização doutrinária a ela associada autorizam que se afirme a existência de uma quarta modalidade de vício de inconstitucionalidade, que se poderia intitular de inconstitucionalidade finalística. Nessa ampla categoria deve-se incluir toda sorte de contradição entre o ato legislativo e os fins que lhe forem assinalados pelas normas constitucionais, ${ }^{4}$ podendo-se mesmo falar em subespécies de inconstitucionalidade finalística, dentre elas destacando-se: (A) a falta de aptidão mínima da lei para atingir o objetivo traçado pela Constituição e ao qual pretendeu se submeter o legislador; (B) o excesso na promoção de determinada medida restritiva, embora ajustada, a princípio, à teleologia constitucional; $(C)$ a inadequada otimização de duas normas-

2 Essas Constituições são aquelas que Jorge Miranda denomina de "programáticas, directivas ou doutrinais" e que, "além da organização política, estabelecem programas, directrizes e metas para a actividade do Estado no domínio económico, social e cultural”: Manual de direito constitucional. 3. ed. Coimbra: Coimbra Ed., 1996, t. 2, p. 26.

3 A separação de Poderes e sua principiologia tornam extremamente delicada a atuação da jurisdição constitucional no sentido de superar situações de omissão do legislador, mormente quando a implementação de preceitos constitucionais exija mais do que a simples edição de lei ou ato normativo (o que ocorre quando se está diante de norma tipicamente programática). Isso não importa em menosprezo à contribuição que o controle de constitucionalidade das omissões legislativas possa trazer, por mais modesta que seja. No entanto, o aperfeiçoamento do processo legislativo e o reforço aos instrumentos de participação popular na elaboração legislativa parecem oferecer melhores condições de êxito na questão do combate à inconstitucionalidade por omissão.

4 Anote-se que a inconstitucionalidade finalística é mais facilmente identificada mediante o confronto entre o ato legislativo e norma constitucional que estabeleça fim específico a ser por ele alcançado, considerada a matéria regulada (p.e., a norma do art. 37 , IX, ou a do art. $173, \int 4^{\circ}$, ambos da Constituição brasileira de 88), comparativamente à utilização de normas de fins gerais (como a do art. $3^{\circ}$ da Constituição referida, que fixa os objetivos fundamentais do Estado brasileiro) como parâmetro de aferição do desvio de poder legislativo. 
princípio potencialmente colidentes, exacerbando-se a força prescritiva de uma delas em detrimento ao núcleo essencial de outra; (D) a deficiente estruturação interna do ato legislativo, quer sob o aspecto formal, quer sob o aspecto de conteúdo, tornando-o inábil à consecução do fim (mediato) que lhe é inerente, no plano da segurança jurídica. ${ }^{5}$

Nas três primeiras subespécies acima indicadas (controle de adequação, excesso de poder legislativo e desbalanceamento entre meios e fins) pode-se falar em controle de proporcionalidade, o que já não ocorre na quarta subespécie, o que mostra a abrangência maior da inconstitucionalidade finalística em relação ao denominado juízo de proporcionalidade do ato legislativo.

O objetivo deste trabalho é avaliar, sumariamente, o atual estágio de desenvolvimento da técnica da proporcionalidade no controle abstrato de normas brasileiro, tendo presente que as decisões proferidas pelo Supremo Tribunal Federal nessa modalidade de controle são dotadas de efeitos erga omnes e vinculantes, ${ }^{6}$ modelando a atuação da jurisdição constitucional no âmbito do controle concreto-incidental, de efeitos inter partes. Não se examinará, pois, quer a utilização do juízo de proporcionalidade no controle de constitucionalidade concreto-incidental, quer a transposição (pertinente ou não) da técnica em outras manifestações da função jurisdicional, fora do campo do controle da constitucionalidade de leis e atos normativos.

5 A simples discrepância entre o fim buscado pelo legislador, tal qual revelado pelas disposições do ato legislativo, e determinada disposição constitucional finalística, especificamente vinculante de seu atuar, resolve-se com o uso da categoria da inconstitucionalidade material, com bem observa Gomes Canotilho, na obra Direito constitucional e teoria da Constituição. 7. ed. Coimbra: Almedina, 2003, p. 1.319: "É certo que muitas vezes é a própria Constituição que subordina a lei a fins especiais (...). Estes casos pressupõem e exigem uma maior atenção em relação às particulares condições e pressupostos a que as normas constitucionais subordinam a validade da lei, mas não conduzem necessariamente à figura do desvio do poder; há, sim, inconstitucionalidade material por violação dos fins constitucionalmente prescritos."

${ }^{6}$ Os principais instrumentos do controle abstrato de normas no Brasil são a ação direta de inconstitucionalidade e a ação declaratória de constitucionalidade, a primeira tendo por objeto lei ou ato normativo federal ou estadual e, a segunda, lei ou ato normativo federal (art. 102, I, a, da CF). Conforme estabelece o $\ 2^{\circ}$, do art. 102, da Constituição de 1988, "as decisões definitivas de mérito, proferidas pelo Supremo Tribunal Federal, nas ações diretas de inconstitucionalidade e nas ações declaratórias de constitucionalidade produzirão eficácia contra todos e efeito vinculante, relativamente aos demais órgãos do Poder Judiciário e à administração pública direta e indireta, nas esferas federal, estadual e municipal". Existe também controle abstrato de normas em nível estadual, competindo aos Tribunais de Justiça dos Estados o julgamento de ações diretas de inconstitucionalidade de leis ou atos normativos estaduais ou municipais em face da Constituição da respectiva unidade federada (art. 125, $₫ 2^{\circ}$, da CF). 


\section{A natureza da exigência de proporcionalidade}

Na maior parte dos Estados regidos por Constituições dotadas de supremacia hierárquica, a exigência de que os atos legislativos apresentem conteúdo prescritivo proporcional, em relação às normas finalísticas que circunscrevem, na espécie, a liberdade de conformação do legislador, não está revestida de caráter normativo. Ou seja, em geral, as Constituições não contêm norma expressa ou mesmo implícita consagrando um pretenso dever de proporcionalidade legislativa. A exigência de proporcionalidade decorre da necessidade de que as leis e atos normativos subalternos observem as normas constitucionais de cunho teleológico, enquanto decorrência da própria supremacia hierárquica dessas normas. ${ }^{7}$ Constitui, pois, um modo peculiar de aferir a constitucionalidade de atos legislativos, o qual importa na atuação dos órgãos de controle em zona muito próxima da discricionariedade deferida ao legislador pela própria Constituição, sob o amparo do princípio da separação dos Poderes.

Em algumas situações, para se avaliar a proporcionalidade de uma lei há que se investigar os seus potenciais efeitos na realidade fática (é o que sucede no controle de adequação ou de excesso de poder legislativo). Em outras, o juiz constitucional se vê envolvido em complexas operações hermenêuticas, no sentido de fixar o núcleo significativo básico e a extensão aceitável do conteúdo dispositivo de normas constitucionais de reduzida densidade semântica (princípios constitucionais ou regras constitucionais veiculadoras de conceitos indeterminados), cuja observância simultânea se imponha ao legislador, realizando, a seguir, o ajuste que permita a conflituosa dupla incidência (controle de proporcionalidade em sentido estrito). ${ }^{8}$

Compatível com essa afirmativa é a conclusão assentada por Humberto Ávila, em sua obra

Teoria dos princípios: da definição à aplicação dos princípios jurídicos. 9. ed. São Paulo: Malheiros, 2009, p. 179, a propósito das exigências, por ele diferenciadas, da razoabilidade, da proporcionalidade e da proibição de excesso: "De qualquer forma, as exigências decorrentes da razoabilidade, da proporcionalidade e da proibição de excesso vertem sobre outras normas não, porém, para atribuir-lhes sentido, mas para estruturar racionalmente sua aplicação. Sempre há uma outra norma por trás da aplicação da razoabilidade, da proporcionalidade e da excessividade. Por esse motivo, é oportuno tratá-las como metanormas."

8 Daí se poder falar em exame fático-normativo da proporcionalidade ou em exame interpretativo-normativo da proporcionalidade. Essa dicotomia tem emergido em inúmeros textos doutrinários que analisam os diversos elementos do teste de proporcionalidade aplicado pela Corte Constitucional alemã à legislação restritiva de direitos fundamentais, radicando-se, ao que tudo indica, no pensamento de Robert Alexy: "Do subprincípio de proporcionalidade em sentido estrito se segue que os princípios são mandados de otimização com relação às possibilidades jurídicas. De outra parte, os subprincípios da necessidade e da adequação derivam do caráter dos princípios como mandados de otimização com relação às possibilidades fáticas." In: Teoría de los derechos fundamentales. 2. ed. esp., trad. e introd. de Carlos Bernal Pulido, Madri, Centro de Estudios Politicos y Constitucionales, 2007, p. 92-93. 
No Brasil, a Constituição Federal de 5 de outubro de 1988, na linha das anteriores, não contempla, expressamente, o dever de proporcionalidade legislativa. Sem se aperceber que a exigência de proporcionalidade é ínsita ao controle de constitucionalidade finalístico, tanto a doutrina quanto a jurisprudência tem procurado revestir a máxima da proporcionalidade de caráter normativo, com o propósito de legitimar a sua utilização, aludindo, pois, a um suposto "princípio da proporcionalidade". Desse modo, o termo "princípio" aparece, invariavelmente, nos textos doutrinários e decisões judiciais no sentido de norma-princípio e não no de técnica de controle de constitucionalidade e de interpretação normativa.

O fundamento normativo da exigência de proporcionalidade residiria, segundo alguns, no princípio do Estado de Direito, proclamado no artigo $1^{\circ}$, caput, da Constituição Federal, consistindo em um subprincípio dele decorrente. Tal ilação apenas seria possível, se fosse atribuído ao princípio do Estado de Direito um sentido demasiadamente amplo, o que o tornaria funcionalmente irrelevante, porquanto, tal qual o princípio da dignidade da pessoa humana, não há instituto ou técnica jurídica que com ele não apresente conexão.

Outros sustentam que a exigência de proporcionalidade está condensada em norma constitucional implícita, decorrente do sistema de direitos e garantias fundamentais, ressaltando que a Constituição vigente, como também as anteriores, a partir da republicana de 1891, atribuiu a esse sistema um caráter aberto e dinâmico. ${ }^{9}$ Assim é que, ao conceder habeas corpus, no ano de 1968, o Supremo Tribunal Federal declarou, incidentalmente, a inconstitucionalidade de dispositivo legal que impedia os acusados da prática de crimes contra a segurança nacional de exercerem qualquer atividade profissional, na esfera pública ou privada, apontando a "desproporção entre a situação do acusado e as consequências da medida". Nessa decisão, o Ministro-relator fez expressa referência ao artigo $150, \mathbb{3} 3$, da Constituição de 1967, que então servia de base ao reconhecimento de direitos e garantias fundamentais implícitos..$^{10}$

9 Com efeito, de acordo com o $\$ 2^{\circ}$, do art. $5^{\circ}$, da CF de 88 , “os direitos e garantias expressos nesta Constituição não excluem outros decorrentes do regime e dos princípios por ela adotados, ou dos tratados internacionais em que a República Federativa do Brasil seja parte".

10 Trata-se do acórdão proferido no $\mathrm{HC} \mathrm{n}^{\circ}$ 45.232, da relatoria do Min. Themístocles Cavalcanti. Ao comentar esse importante precedente, anota Gilmar Mendes que "um exame mais acurado da referida decisão, com a utilização dos recursos da moderna doutrina constitucional, parece indicar que, em verdade, a Corte se valeu da cláusula genérica de remissão contida no art. 150, \35, da Constituição de 1967, para poder aplicar, sem risco de contestação, a idéia de proporcionalidade da restrição como princípio constitucional": cf. Curso de direito constitucional. Gilmar Ferreira Mendes, Inocêncio Mártires Coelho e Paulo Gustavo Bonet Blanco. São Paulo: Saraiva, 2007, p. 316. 
A caracterização da exigência de proporcionalidade como garantia de direito fundamental implícita também se mostra extremamente problemática. Em primeiro lugar, porque teria que ser extraída de algum princípio expresso no texto constitucional. Antes da Constituição de 1988, o que se tentava demonstrar é que a legislação restritiva de liberdades públicas deveria observar a proporcionalidade, em sentido amplo, sob pena de inconstitucionalidade, vício esse, contudo, que resultava muito mais do confronto entre a lei fiscalizada e a liberdade restringida do que entre aquela e suposta norma-princípio impositiva da proporcionalidade, totalmente desnecessária para o objetivo assinalado. Entretanto, além de desnecessária, a identificação da norma-matriz da proporcionalidade revelava-se, então, contraproducente, na medida em que circunscrevia a exigência ao campo da proteção das liberdades públicas, sendo certo que se trata de categoria teorética de grande utilidade também em outros domínios do sistema constitucional.

De qualquer forma, a partir da vigência da Constituição de 88 , tornou-se bem mais sólida a orientação dos que divisam um fundamento normativo para a exigência da proporcionalidade, tomando-a como autêntica norma-princípio. Com efeito, o artigo $5^{\circ}$, inciso LIV, da atual Constituição consagrou, expressamente, o denominado princípio do devido processo legal. ${ }^{11}$ Ora, é bastante conhecida a trilha evolutiva da cláusula do due process of law no direito constitucional estadunidense, fonte inspiradora do preceito constitucional brasileiro, partindo de uma concepção estritamente processual para alcançar sentido bem mais amplo (substantive due process), hábil à declaração da inconstitucionalidade de leis não razoáveis ou desproporcionais. ${ }^{12}$ Destarte, pode-se, presentemente, aludir a uma garantia constitucional de proporcionalidade, radicada no princípio do devido processo legal, em sua dimensão substantiva. ${ }^{13}$

$\overline{11}$ Estabelece o dispositivo que "ninguém será privado da liberdade ou de seus bens sem o devido processo legal".

12 Em breve referência à evolução da cláusula do due process of law, a partir de sua introdução no direito constitucional estadunidense, por meio das Emendas V e XIV da Constituição de 1787, Ada Pellegrini Grinover ensina: "Ao lado do procedural due process, sustenta-se a existência de um substantive due process, garantindo o exercício pleno e absoluto dos direitos de liberdade e de propriedade (em sentido amplo). A cláusula não mais se limita à determinação processual de direitos substanciais, mas se estende à garantia de que seu gozo não seja restringido de modo arbitrário ou desarrazoado.” In: As garantias constitucionais do direito de ação. São Paulo: Revista dos Tribunais, 1973, p. 36.

13 O STF, ao se reportar à exigência de proporcionalidade da legislação, após o advento da Carta de 88 , a tem lastreado na cláusula do art. $5^{\circ}$, LIV, como se pode constatar em diversos acórdãos: e.g., ADI no 1.158-8/AM (j. 19-12-1994; DJ 26-5-1995); RE no 543.974-7/MG (26-3-2009; DJ 28-5-2009). Entretanto, autores fortemente influenciados pelo pensamento jurídico alemão, como Luís Virgílio Afonso da Silva, insistem em recusar à exigência de proporcionalidade a natureza de norma-princípio, preferindo caracterizá-la como decorrência lógica da estrutura dos direitos fundamentais enquanto princípios jurídicos: "Se se aceita, portanto, a definição de 
No entanto, há que se ter presente que a garantia do devido processo legal atribui natureza normativa à exigência de proporcionalidade apenas quando voltada à legislação restritiva de direitos fundamentais. Como já se disse, o controle de proporcionalidade decorre da supremacia hierárquica de normas constitucionais finalísticas que permeiam todo o Texto Magno. Portanto, mesmo que inexista fundamento normativo para se exigir que os atos legislativos sejam adequados e não excessivos em relação aos fins que se pretende alcançar, bem como equilibrados na harmonização de fins potencialmente conflituosos, cabe ao órgão de controle verificar a existência ou não dessa modalidade de vício de inconstitucionalidade.

Por conseguinte, no sistema jurídico-constitucional brasileiro as frequentes referências que operadores e doutrinadores fazem ao "princípio da proporcionalidade" não exclui a constatação de que, sob um mesmo rótulo, se está a manipular categorias conceituais distintas. Muitas vezes o que se tem em vista é a norma-matriz da garantia de proporcionalidade legislativa, derivada da exigência de que a legislação restritiva de direitos fundamentais observe o devido processo legal; em outras situações, trabalha-se com mero postulado hermenêutico, a orientar o intérprete-aplicador na fiscalização da constitucionalidade de leis que busquem harmonizar normas finalísticas de incidência simultânea e, por isso mesmo, aparentemente colidentes; ${ }^{14}$ por último, há o uso, já mencionado, da proporcionalidade enquanto modo peculiar de controle da constitucionalidade de leis e atos normativos, tendo em vista o pleno acatamento dos fins que a Constituição impõe ao legislador.

\section{Proporcionalidade e razoabilidade}

Qualquer elucubração teorética em torno da exigência de proporcionalidade no sistema jurídico brasileiro depara-se com a dificuldade decorrente do seu uso diversificado, que abarca, desde situações direta (proporcionalidade como técnica de

princípio jurídico como mandamento de otimização, necessário é também aceitar a aplicação da regra da proporcionalidade, pois ambos guardam uma relação de implicação." Cf. o artigo O proporcional e o razoável. São Paulo: Revista dos Tribunais, 798:45, abr. 2002.

14 Nesse sentido, a exposição de Friedrich Müller, em seus Métodos de trabalho do direito constitucional. 3. ed. Trad. Peter Naumann. Rio de Janeiro: Renovar, 2005, p. 77, sobre o princípio da concordância prática, enquanto subespécie dos elementos tradicionais de interpretação (mormente o lógico-sistemático): “O princípio da concordância prática também apresenta uma estreita relação com o princípio da unidade da constituição. Ele não formula apenas no caso da existência de contradições normativas, mas também nos casos de concorrências e colisões e.g. de várias normas de direitos fundamentais no sentido de uma sobreposição parcial dos seus âmbitos de vigência, a tarefa de traçar aos dois ou a todos os 'bens jurídicos' (de direitos fundamentais) envolvidos as linhas de fronteira de modo tão 'proporcional' que eles cofundamentem também no resultado a decisão sobre o caso." 
controle de constitucionalidade) ou indiretamente (proporcionalidade como princípio normativo ou como recurso hermenêutico) referentes à avaliação da higidez constitucional de leis e atos normativos, até relações, igualmente variadas, que se fazem no plano da mera aplicação normativa de caráter concreto, no sentido de buscar a solução mais justa, equânime, vale dizer, proporcional. ${ }^{15}$ Isso sem contar que, por vezes, a alusão à proporcionalidade ocorre no contexto da efetivação do princípio da isonomia, quer tendo em mira o legislador, quer os órgãos, administrativos e judiciários, incumbidos da aplicação das normas por aquele editadas. ${ }^{16}$

A essa dificuldade soma-se outra, associada à disputa terminológico-conceitual que se estabeleceu, no Brasil, em torno das noções de proporcionalidade e razoabilidade. Diante do recurso frequente a um e outro termo por parte dos estudiosos e operadores do sistema, nas situações anteriormente apontadas, cabe perquirir se há perfeita correspondência entre os conceitos de proporcionalidade e razoabilidade, se há parcial coincidência ou se ambos se reportam a objetos distintos. A propósito, na doutrina brasileira as três variantes são assumidas por ardorosos defensores, que travam entre si debate tão intenso quanto infrutífero, em face da diferença entre os fundamentos sistêmicos das concepções em contenda.

Em bases objetivas, historicamente demonstráveis, o que se sabe é que a difusão do termo razoabilidade partiu do sistema jurídico estadunidense, ao passo que a referência ao termo proporcionalidade se tornou usual por influência do constitucionalismo germânico.

De fato, faz parte da própria essência dos sistemas de common law a exigência de que as normas jurídicas, sejam elas as estabelecidas pelos magistrados para a solução de um caso concreto (case law), sejam elas as formuladas pelo legislador (statute

$\overline{15}$ Referindo-se à noção de razoabilidade, Humberto Ávila descreve algumas situações em que se pode vislumbrar o uso da proporcionalidade no plano da aplicação normativa, como, por exemplo, aquelas em que se busca a adequada "harmonização da norma geral com o caso individual" (o que pode implicar em afastar o caso individual do campo de incidência do preceito) ou em que se estabelece "uma relação de equivalência entre a medida adotada e o critério que a dimensiona" (e.g., na dosagem da pena, que há de levar em conta as circunstâncias do crime). Cf. Teoria dos princípios, cit., p. 152-5 e 158.

16 Nesse sentido a observação de Willis Santiago Guerra Filho, ao dissertar sobre as relações entre o princípio da proporcionalidade e a Teoria do Direito, na obra de coletânea GRAU, Eros Roberto; GUERRA FILHO, Willis Santiago. (Org.). Direito constitucional: estudos em homenagem a Paulo Bonavides. 1. ed. São Paulo: Malheiros, 2003, p. 278-279: “Os princípios da isonomia e da proporcionalidade, aliás, acham-se estreitamente associados, sendo possível, inclusive, que se entenda a proporcionalidade como incrustada na isonomia, pois, como se encontra assente em nossa doutrina, com grande autoridade, o princípio da isonomia traduz a idéia aristotélica - ou, antes, 'pitagórica', como prefere Del Vecchio - de 'igualdade proporcional', própria da 'justiça distributiva', 'geométrica', que se acrescenta àquela 'comutativa', 'aritmética', meramente formal - aqui, igualdade de bens; ali igualdade de relações.” 
law), devem observar determinados padrões de razoabilidade e racionalidade. ${ }^{17}$ Daí a larga abrangência emprestada à noção de razoabilidade no sistema jurídico estadunidense, que, ao contrário do sistema inglês, carente de normas constitucionais dotadas de supremacia hierárquica, permite não apenas a equilibrada solução de casos concretos submetidos à jurisdição, mas, também, o controle finalístico da legislação, tomando como parâmetro a cláusula do devido processo legal, em sua dimensão substantiva, incompatível com leis inadequadas, excessivas, teleologicamente desbalanceadas ou até mesmo irracionais, em face da inconsistência interna, formal ou material, de seus comandos. ${ }^{18}$

$\mathrm{Na}$ Alemanha, muito embora o termo proporcionalidade também possa ser empregado em acepção genérica, por vezes indicativa de princípio constitucional (implícito) ou de técnica de interpretação de princípios constitucionais de incidência simultânea ou, ainda, de raciocínio que permite otimizar a aplicação de normas jurídicas de conteúdo variado, o certo é que, a partir da jurisprudência do Tribunal Constitucional, construiu-se, doutrinariamente, um conceito bem mais preciso e, na mesma medida, bem mais restrito de proporcionalidade. Cuida-se, nesse caso, de técnica de controle da constitucionalidade de legislação restritiva de direitos fundamentais, a qual tem em vista direitos de liberdade ou de propriedade, vale dizer, espaços reservados à autonomia individual, passíveis de sofrerem compressão fundada na preservação de outros direitos fundamentais de igual porte hierárquico ou na observância de normas constitucionais, que, explícita ou implicitamente, consagrem certas imposições da vida em coletividade. Por meio do controle de proporcionalidade o Bundesverfassungsgericht verifica a aptidão da legislação restritiva para alcançar os objetivos a que se predispõe (adequação), a existência ou não de medidas alternativas menos gravosas ao direito restringido (necessidade) e se a legislação fiscalizada consegue harmonizar, satisfatoriamente, a norma-sede do direito fundamental comprimido com as normas constitucionais contrapostas, preservando o núcleo irredutível de cada preceito (proporcionalidade em sentido estrito). ${ }^{19}$

17 René David, na obra clássica, Os grandes sistemas do direito contemporâneo, 2. ed. bras., trad. Hermínio A. Carvalho. São Paulo: Martins Fontes, 1993, p. 349, bem sintetiza essa característica estrutural do common law: "A common law foi elaborada, originariamente, sobre a razão, dissimulada sob a ficção do costume geral imemorial do reino."

18 Sobre a origem e extensão do princípio da razoabilidade nos Estados Unidos da América consulte-se Carlos Roberto Siqueira Castro. A Constituição aberta e os direitos fundamentais: ensaios sobre o constitucionalismo pós-moderno e comunitário. 1. ed. Rio de Janeiro: Forense, 2003, p. $75-81$

19 No tocante ao controle de proporcionalidade na jurisprudência produzida pelo Tribunal Constitucional alemão, a partir dos anos setenta do século passado, consulte-se Gilmar Ferreira Mendes et al. Curso de direito constitucional, cit., p. 320-323. 
Se a noção de razoabilidade perpassa todo o sistema jurídico estadunidense, dada a imbricação com os seus fundamentos primeiros, o conceito de proporcionalidade acima exposto constitui categoria teórica circunscrita ao sistema de controle de constitucionalidade germânico, observando-se estar sua elaboração mais refinada, sem sombra de dúvida, associada à especialização no trato das questões constitucionais, a que conduz a concentração da competência para a fiscalização da legislação subalterna.

A doutrina brasileira mais recente, sob indisfarçável influência do constitucionalismo alemão, registra forte tendência no sentido de considerar a exigência de proporcionalidade nos moldes da jurisprudência da Corte de Karlsruhe e, em face dessa premissa, ou atribui ao apelo à razoabilidade valor meramente argumentativo, vendo na plasticidade que o caracteriza um impedimento à sua transcrição em bases cientificamente consistentes, ou o confina a domínios estranhos ao controle da constitucionalidade da legislação restritiva de liberdades públicas, assinalando que a existência de categoria teórica dotada de maior precisão deveria ser acompanhada da escolha de terminologia uniforme, exatamente aquela proveniente do Direito germânico. ${ }^{20}$

Trata-se, a meu juízo, de um bom exemplo de utilização deformada dos estudos comparativos. Não se questiona que o Direito Comparado, dentre outras serventias, pode ser extremamente útil à compreensão do direito nacional. ${ }^{21}$ Entretanto, a importação de categorias doutrinárias alienígenas deve ser feita de modo extremamente criterioso. Não basta a verificação da compatibilidade da construção teórica com o ordenamento jurídico nacional: faz-se necessário perquirir de sua funcionalidade, isto é, se contribui do modo mais eficiente possível para a sistematização do direito pátrio.

Sob essa inspiração, entendo que, somente no âmbito da Teoria do Direito, faz sentido a estruturação das exigências de proporcionalidade ou razoabilidade em termos tão amplos que cubram todas as situações em que operadores do sistema se veem na contingência de atendê-las. $\mathrm{O}$ pragmatismo inerente à função regulatória do direito positivo torna imprescindível que as investigações científicas de cunho dog-

$\overline{20}$ Humberto Ávila, embora aponte a extrema amplitude da categoria razoabilidade, a insere no conjunto dos postulados normativos aplicativos, por ele definidos como "normas imediatamente metódicas que instituem os critérios de aplicação de outras normas situadas no plano do objeto da aplicação" e que, portanto, "qualificam-se como normas sobre a aplicação de outras normas". Entretanto, a abrangência e plasticidade da razoabilidade não lhe permitiriam adentrar os domínios, mais precisamente demarcados, da proporcionalidade (conceituada sob o enfoque da jurisprudência e doutrina alemãs), não autorizando, pois, a utilização indiscriminada dos dois termos. Cf. Teoria dos princípios, cit., p. 122, 151 e 176-179, anotando-se que o autor ainda faz alusão a outro postulado normativo aplicativo próximo às categorias da razoabilidade e da proporcionalidade: a proibição de excesso.

21 Em relação às diversas funções do Direito Comparado, veja-se DAVID, René. Os grandes sistemas, cit., p. 2-10. 
mático sejam feitas de modo segmentado. No que concerne à Ciência do Direito Constitucional, necessariamente vinculada a determinado sistema jurídico positivo, importa circunscrever a análise do tema do proporcional e do razoável ao controle de constitucionalidade de leis e atos normativos, sob pena de se perder o investigador no labirinto representado pelos usos diversificados de ambas as categorias.

Nessa linha de raciocínio, que retoma as considerações feitas no item 1, retro, as exigências de proporcionalidade ou razoabilidade enquanto critérios de aferição da constitucionalidade de atos legislativos ${ }^{22}$ devem corresponder, em nível conceitual, à noção de vício de inconstitucionalidade finalística.

Ora, a incorporação ao sistema jurídico brasileiro do postulado da proporcionalidade, nos termos em que é utilizado pela jurisprudência e doutrina germânicas, mostra-se, à luz do critério preestabelecido, flagrantemente inadequada, pela simples razão de que nele não estariam compreendidas inúmeras outras situações em que há vício de inconstitucionalidade teleológica. O controle de proporcionalidade alemão, como já restou assentado, é sim uma técnica de aferição da existência ou não de inconstitucionalidade finalística, porém aplicável unicamente à legislação restritiva de direitos fundamentais de liberdade e de propriedade. Os elementos em que se decompõe, de aferição da adequação, necessidade e proporcionalidade em sentido estrito da legislação controlada, entrelaçam-se em torno desse objetivo unitário. No entanto, se o denominado "teste de proporcionalidade", estruturado em três etapas logicamente ordenadas, é de ser aplicado apenas a determinados atos legislativos, o mesmo não se diga do atendimento aos elementos do teste, considerados separadamente. Com efeito, diante das normas-fim estabelecidas no Texto Magno, todo e qualquer ato legislativo há que se mostrar adequado à consecução dos objetivos a que se predisponha a atingir; ${ }^{23}$ da mesma maneira, as leis

22 É sabido que, na Alemanha, a doutrina tem se referido ao requisito da proporcionalidade também no campo da omissão legislativa, aludindo-se à proteção insuficiente (untermassverbot) dispensada pelo legislador, diante das normas finalísticas agasalhadas pela Constituição (cf. Gilmar Mendes et al. Curso..., p. 323). Todavia, não me parece recomendável um tratamento unitário da exigência de proporcionalidade, de modo a abarcar atos e omissões legislativas, porquanto no primeiro caso atuará como requisito de validade de lei existente, ao passo que, no segundo, como mero elemento caracterizador de omissão inconstitucional (ausência de lei).

23 Um bom exemplo de caracterização de inconstitucionalidade finalística por inadequação do ato legislativo, fora do campo da restrição às liberdades públicas e sem a aplicação do teste de proporcionalidade, pode ser encontrado no controle preventivo realizado pelo Conselho Constitucional francês, que não tem titubeado em proclamar a inconstitucionalidade, por "erro manifesto de apreciação", de leis configuradoras de distritos eleitorais, que não avaliam adequadamente as condições demográficas subjacentes e, por conta disso, revelam total falta de aptidão para a promoção do princípio da igualdade de voto. Sobre a técnica de controle do erro manifesto de apreciação, veja-se ROUSSEAU, Dominique. Droit du contentieux constitutionnel. Paris: Montchrestien, 1990, p. 127-129. 
implementadoras de princípios constitucionais aparentemente conflitantes, devem harmonizá-los na justa medida, isto é, sem afetar o seu núcleo irredutível. ${ }^{24} \mathrm{Em}$ todas as situações em que se investiga a presença de inconstitucionalidade finalística, sob a ótica da adequação, da necessidade ou da proporcionalidade em sentido estrito, consideradas separadamente ou reunidas em um teste unitário, há um ponto comum, qual seja, a relação que o órgão de controle busca estabelecer entre os meios previstos no ato legislativo fiscalizado e os fins constitucionais. ${ }^{25}$ Portanto, não há razão para não se estender a exigência de proporcionalidade a todas essas situações, o que, de um lado lhe atribuiria extensão mais próxima à do conceito de inconstitucionalidade finalística, e, de outro, aproximaria tal categoria doutrinária do uso, reconhecidamente mais largo, que o Supremo Tribunal Federal vem fazendo do controle de proporcionalidade, em comparação à Corte congênere sediada em Karlsruhe.

Por seu turno, dada a sua extrema plasticidade, o postulado da razoabilidade se mostra apto a também identificar todas as situações de inconstitucionalidade finalística em que se pode vislumbrar desproporcionalidade (inadequação, desnecessidade, desbalanceamento na implementação de normas finalísticas concorrentes) e, além destas, aquelas em que não há, propriamente, desproporção entre meios e fins e sim inaptidão formal do ato legislativo, de modo a não permitir a compreensão de seu significado (obscuridade, laconicidade etc.) ${ }^{26}$ ou contraditoriedade ou ilogicidade (irracionalidade) em seu conteúdo dispositivo. ${ }^{27}$

$\overline{24}$ O que também ocorre em matérias que não envolvam direitos fundamentais. Por exemplo, a lei complementar federal delimitadora do período em que podem ser criados Municípios deve conciliar a expressão "período determinado", utilizada no art. 18, \4 4 da Constituição de 1988, com a liberdade de criação de entes locais, o que impede a fixação de lapsos temporais por demais exíguos.

25 Humberto Ávila aduz, com inteira propriedade, que "sem uma relação meio/fim não se pode realizar o exame do postulado da proporcionalidade, pela falta dos elementos que o estruturem". Cf. Teoria dos princípios, cit., p. 163.

26 Na doutrina constitucional mais atualizada, especula-se sobre a existência de uma nova categoria de vício de inconstitucionalidade concernente à estrutura formal do ato legislativo, inconfundível com o vício de procedimento ou de competência e aplicável às situações em que a absoluta falta de clareza ou a reduzidíssima prescritividade do texto legislativo comprometem a segurança jurídica inerente à função de regulação. Abrir-se-ia, pois, um campo fértil ao controle da qualidade da técnica legislativa, como demonstrado por Laure Milano, no artigo Contrôle de constitutionnalité et qualité de la loi, Revue de Droit Public, Paris, Librairie Générale de Droit et de Jurisprudence, 3:637-71, maio/jun. 2006.

27 Gomes Canotilho bem se apercebeu da diferença entre a desproporcionalidade ou irrazoabilidade externa do ato legislativo (relação defeituosa entre os meios que preconiza e os fins constitucionais a que se vincula) e a sua irrazoabilidade interna: "Contra uma concepção tão absoluta da lei como ato livre no fim, movem-se hoje poderosas críticas que tendem a assinalar dois momentos teleologicamente relevantes nos atos legislativos: (i) em primeiro lugar, a lei tem, por vezes, função de execução, desenvolvimento ou prossecução dos fins estabelecidos na constituição, pelo que sem- 
Portanto, restrita a análise ao controle de constitucionalidade e vista a proporcionalidade sob uma ótica mais abrangente, de congruência entre meios e fins, conclui-se que, de um modo geral (nos diversos sistemas de controle) e, especificamente, no sistema de controle brasileiro, entre os postulados da proporcionalidade e da razoabilidade existe uma parcial coincidência, sendo o segundo mais amplo que o primeiro, permitindo-lhe total correspondência com as modalidades já identificadas de inconstitucionalidade finalística.

Restaria a questão terminológica. Nas situações em que se está diante de irrazoabilidade externa do ato legislativo, tomando-se como parâmetro normas constitucionais de finalidade, mostra-se viável a alusão a uma ou outra exigência (proporcionalidade e razoabilidade). Ao contrário, a obscuridade ou a ilogicidade patológica do ato legislativo somente podem ser combatidas com apoio no postulado da razoabilidade, tomado sob o ângulo interno. Contudo, na medida em que a razoabilidade pode se referir a outros aspectos da aplicação normativa, estranhos ao controle de constitucionalidade, a ambiguidade decorrente do uso de uma única expressão para a descrição de fenômenos distintos somente pode ser superada com apoio na noção de inconstitucionalidade finalística, unificadora de todas as situações de agressão à Constituição cometida pelo legislador, em que a doutrina e os intérpretes-aplicadores divisam desatendimento às exigências da proporcionalidade ou da razoabilidade.

\section{Elementos do requisito de proporcionalidade e "teste de proporcionalidade"}

Em face do desenvolvimento anterior da matéria, cabe apenas reafirmar que o controle de proporcionalidade envolve a consideração de alguns elementos, destacando-se os da adequação, necessidade e equilíbrio teleológico, como assinalado. Nesse ponto, aliás, parece haver certa tendência à uniformização doutrinária nos Estados cujos ordenamentos jurídicos se filiam à família do civil law, em virtude da influência do direito alemão.

Nem sempre, porém, os mencionados elementos atuam de forma combinada, compondo uma técnica unitária de controle da proporcionalidade. Há, pois, que se distinguir o controle da proporcionalidade em sentido amplo, que compreende todas as situações em que o ato legislativo, embora não contrariando frontalmente os fins

pre se poderá dizer que, em última análise, a lei é vinculada ao fim constitucionalmente fixado; (ii) por outro lado, a lei, embora tendencialmente livre no fim, não pode ser contraditória, irraz̧oável, incongruente consigo mesma." Direito constitucional, cit., p. 1.318. 
que a Constituição lhe assinala, mostra-se incapaz de realizá-los, por absoluta inadequação, excessividade manifesta ou desbalanceamento inaceitável no atendimento a exigências teleológicas simultâneas, do teste de proporcionalidade aplicável, especificamente, à legislação restritiva da liberdade e da propriedade individuais.

No denominado teste de proporcionalidade os três elementos que emergem do apelo à congruência entre meios e fins constituem etapas de um procedimento único e, mais do que isso, etapas que se desenrolam sucessivamente, em uma ordem predeterminada e escalonada, de modo que o insucesso no preenchimento de um sub-requisito basta para a caracterização da desproporcionalidade, mas o exame favorável em uma das etapas não é suficiente para se afirmar a proporcionalidade se existir outra ou outras que sobre ela se assentem. ${ }^{28}$

O primeiro exame a ser feito é o da adequação, o segundo o da necessidade e o terceiro e último o da proporcionalidade em sentido estrito, de sorte que uma lei restritiva de liberdades públicas inadequada apenas por isso já é desproporcional, sem que se passe ao exame dos demais elementos. Constatada a adequação, importa investigar se veicula restrição necessária ou excessiva. Se a conclusão for desfavorável à lei, no tocante a esse segundo requisito, não haverá que se proceder à análise do terceiro, que somente é considerado em relação a atos legislativos adequados e necessários.

\section{A intensidade do controle de proporcionalidade}

No Brasil, o controle de proporcionalidade efetivamente realizado pelos órgãos jurisdicionais ${ }^{29}$ não adquiriu sofisticação tal que nele permita divisar variados graus de intensidade. Ao contrário, a jurisprudência constitucional ainda se ressente de maior precisão na manipulação dessa técnica de controle, razão pela qual às vezes exacerba o conceito de proporcionalidade, de modo a estendê-lo a situações de irrazoabilidade interna do ato legislativo, outras vezes, em sentido inverso, confina-o

\footnotetext{
28 Luís Virgílio Afonso da Silva, no artigo "O proporcional e o razoável”, cit., p. 34, descreve a mesma característica do controle de proporcionalidade de legislação restritiva de direitos fundamentais fazendo referência a uma relação de subsidiariedade que existiria entre os três elementos utilizados.

29 Não se pode olvidar que o sistema de controle de constitucionalidade brasileiro continua sendo, em sua essência, de padrão estadunidense, malgrado apresente nítida tendência à europeização. Assim sendo, todo e qualquer órgão judiciário, nos limites de sua competência, pode controlar a constitucionalidade de leis e atos normativos, controle esse, usualmente, efetuado no caso concreto, cabendo apenas ao Supremo Tribunal Federal e aos Tribunais de Justiça dos Estados e do Distrito Federal a fiscalização abstrata de constitucionalidade, aquele tendo em vista a proteção da Constituição Federal e estes o resguardo das Constituições Estaduais e da Lei Orgânica do Distrito Federal.
} 
aos limites estreitos do teste de proporcionalidade, projetando a sensação de que os juízes e tribunais brasileiros não estabelecem relações consistentes entre proporcionalidade, razoabilidade e inconstitucionalidade finalística, não distinguindo, com clareza, as diversas hipóteses desta categoria de vício de inconstitucionalidade.

O pouco que se pode afirmar sobre o padrão de intensidade do controle em foco é que, no tocante ao controle de leis restritivas dos direitos de liberdade e propriedade, há melhores condições para uma fiscalização mais aprofundada. Isso em razão, por um lado, do apuro técnico obtido com o teste de proporcionalidade,,$^{30}$ mercê de sua larga aplicação no sistema de controle europeu, acompanhada de farta elaboração doutrinária, e, de outro lado, da fundamentação normativa expressa que a Constituição atribuiu ao controle de proporcionalidade nessa matéria, mediante a consagração do princípio do devido processo legal, o que contribui para a aceitação desse modo de impor limites ao legislador.

É de supor, igualmente, que o controle abstrato da proporcionalidade, na medida em que permite um exame mais completo das circunstâncias que cercaram a edição do ato normativo controlado, de sua racionalidade interna e da congruência com os fins constitucionais que se lhe antepõem tende a ser mais profundo do que o exame de proporcionalidade realizado na busca de uma solução equânime para casos concretos e que dependa da superação de prejudicial de constitucionalidade da legislação incidente.

\section{Discricionariedade legislativa e controle de proporcionalidade}

Em todos os sistemas jurídicos em que se pratica o controle de proporcionalidade registram-se advertências doutrinárias sobre o risco de se deixar o campo próprio da fiscalização de constitucionalidade e se ingressar nos domínios da política legislativa. ${ }^{31}$ É certo que o abandono da concepção clássica de que a lei é um ato inteiramente livre quanto ao elemento finalístico importou em restrição à liberdade

30 SANCHÍS, Luis Prieto no artigo Tribunal constitucional y positivismo jurídico. DOXA Cuadernos de Filosofía del Derecho, Alicante, Universidade de Alicante, 23:194, 2000, observa que o maior apuro na argumentação jurídica ao mesmo tempo em que permite o alargamento ou intensificação das técnicas de controle, também atua como fator de contenção do abuso legislativo e do ativismo judiciário.

31 Para exemplificar, invoque-se a lição do constitucionalista português Gomes Canotilho, que, ao examinar a figura do desvio de poder legislativo, por ele tomado no sentido de inconstitucionalidade finalística, observa correr-se "o risco de transformar o juízo da constitucionalidade em juízo de mérito da lei”, observando, com referência à verificação da razoabilidade interna, que, "ao órgão fiscalizador da inconstitucionalidade está vedado valorar se a lei cumpre bem ou mal os fins por ela estabelecidos": Direito constitucional, cit., p. 1.319-20. 
de conformação do legislador. Entretanto, não se pode admitir que, a pretexto de aferir a congruência entre o ato legislativo e os fins constitucionais que sobre ele incidem, transforme-se o órgão de controle em avaliador da conveniência e oportunidade da atuação legislativa, comprimindo, de modo extremamente danoso ao princípio da separação dos Poderes, o espaço em que se deve movimentar livremente o legislador. Daí a necessidade de serem estabelecidas algumas cautelas na manipulação dos elementos compreendidos no controle de proporcionalidade.

Destarte, não se há de proclamar a inconstitucionalidade de ato legislativo por não ser o mais adequado à realização da norma finalística e sim por não ser minimamente adequado a esse objetivo. Em outros termos, se a medida consagrada em lei promove, em alguma medida, o fim constitucional, não pode ser objeto de censura da parte do órgão de controle, ainda que existam outras maneiras mais eficazes de fazê-lo. ${ }^{32}$

$\mathrm{Na}$ hipótese de legislação restritiva de liberdades públicas a verificação da existência ou não de medida menos onerosa ao direito fundamental há que compreender, forçosamente, a comparação entre a providência restritiva determinada pela lei e a medida alternativa. Se as medidas comparadas promovem a finalidade constitucional autorizadora da restrição de igual modo, sendo que a providência alternativa à escolhida pelo legislador é manifestamente menos restritiva ou invasiva, no tocante à esfera de liberdade individual afetada, deve o órgão de controle declarar a inconstitucionalidade finalística da legislação examinada. Sucede, porém, que, amiúde, as medidas restritivas em confronto não promovem o fim que lhes serve de fundamento de igual modo. ${ }^{33}$ Nesse caso, somente há que se decretar a invalidade da opção legal se a medida alternativa a ela for equiparável em termos de eficácia ou até mesmo mais eficaz do que ela, sopesados os diversos aspectos envolvidos na promoção do objetivo constitucional justificador da compressão de liberdade pública. Não assim se a providência determinada pelo legislador for claramente de maior eficácia ou simplesmente não comparável à medida alternativa, por se mostrar mais eficaz em alguns pontos e menos eficaz em outros.

32 Humberto Ávila, em sua Teoria dos princípios, cit., p. 165-170, assume idêntico posicionamento, desdobrando-o em diversos ângulos de análise. Canotilho não discrepa desse entendimento ao aludir à exigência de que a inadequação da lei censurada seja manifesta (isto é, absoluta, total) ou, na expressão advinda do controle preventivo francês, que tenha havido "erro manifesto de apreciação da parte do legislador": Teoria da Constituição, cit., p. 272.

33 Mais uma vez, socorro-me das ponderações atiladas de Humberto Ávila, ao tratar da "comparação entre os efeitos da utilização dos meios alternativos e os efeitos do uso do meio adotado pelo Poder Legislativo ou pelo Poder Executivo": “A dificuldade desse exame reside no fato de que os meios promovem os fins em vários aspectos (qualitativo, quantitativo, probabilístico). Um meio não é, de todos os pontos de vista, igual a outro. Em alguma medida, e sob algum ponto de vista, os meios diferem entre si na promoção do fim. Uns promovem o fim mais rapidamente, outros mais vagarosamente; uns com menos dispêndios, outros com mais gastos; uns são mais certos, outros mais incertos; uns são mais simples, outros mais complexos; uns são mais fáceis, outros mais difíceis, e, assim, sucessivamente.” Teoria dos princípios, cit., p. 171. 
$\mathrm{Na}$ utilização de elemento correspondente à proporcionalidade em sentido estrito também há de prevalecer a diretriz doutrinária que, sem ofensa à Constituição, mais preserve a discricionariedade legislativa e, portanto, o princípio democrático, do qual é indissociável a liberdade de escolha dos órgãos representação política, observados os requisitos mínimos de juridicidade impostos pela Constituição. Ainda no campo da restrição a direitos de liberdade, tem prevalecido entre os autores brasileiros o entendimento de que um ato legislativo é proporcional stricto sensu na medida em que a importância assumida pela providência de compressão, para a promoção do fim constitucional que a justifica, guarda uma correlação aceitável com o nível de restrição imposto ao direito fundamental..$^{34}$ Que o Poder Judiciário, ao solucionar casos concretos com base em princípios constitucionais de incidência simultânea, lance mão de tal técnica de otimização, nada há a objetar. Entretanto, nas situações de intermediação legislativa entre o texto constitucional e as decisões judiciais, deve ser respeitado o balanceamento promovido pelo legislador, salvo se houver exacerbado a força prescritiva de uma das normas-princípio em cotejo, em detrimento ao núcleo essencial ${ }^{35}$ de outra. ${ }^{36}$

Embora o foco de análise esteja situado sobre o controle de proporcionalidade e não da razoabilidade interna do ato legislativo, cabe o registro de que também esta deve ser aferida de modo respeitoso à liberdade de conformação do legislador, proscrevendo-se apenas as leis absolutamente ineptas, quer sob o ângulo de sua estruturação formal (obscuridade, laconicidade), quer sob o viés de seu conteúdo dispositivo (contraditoriedade, ilogicidade).

\section{O controle de proporcionalidade na jurisprudência do STF}

A jurisprudência do Supremo Tribunal Federal, notadamente, após o advento da Constituição de 5 de outubro de 1988, tem feito uso das diferentes modalidades de inconstitucionalidade finalística, muito embora revele certa imprecisão ao trabalhar com os conceitos de razoabilidade e proporcionalidade, que, como visto, nem sempre se identificam.

\footnotetext{
34 Nesse sentido, por exemplo, manifestam-se Luís Virgílio Afonso da Silva. O proporcional e o razoável, cit., p. 40, e Humberto Ávila. Teoria dos princípios, cit., p. 173.

35 Acerca da garantia do conteúdo essencial das normas definidoras de direitos fundamentais, como autêntica restrição constitucional às restrições legislativas ao exercício de direitos fundamentais, veja-se Robert Alexy, Teoría de los derechos fundamentales, cit., p. 257-262.

36 Luís Virgílio Afonso da Silva reconhece que, mesmo na doutrina germânica em que se abebera, o modo de se conceber esse derradeiro elemento da exigência de proporcionalidade tem gerado muita polêmica. Segundo ele, Bernhard Schlink, "por exemplo, sugere que a proporcionalidade em sentido estrito deve garantir o núcleo essencial do direito restringido, sem a necessidade de sopesamento": cf. O proporcional e o razoável, cit., p. 40, nota 60.
} 
Ao deferir pedido de medida liminar na Ação Direta de Inconstitucionalidade $\mathrm{n}^{\mathrm{o}}$ 1.158-8/AM, tendo por objeto dispositivo de lei estadual que concedera aos servidores inativos vantagem pecuniária correspondente ao adicional das férias que seriam gozadas se estivessem em atividade, o STF fundamentou a decisão com o argumento da falta de razoabilidade do preceito impugnado, anotando-se na ementa do acórdão:

A norma legal que concede a servidor inativo gratificação de férias correspondente a um terço $(1 / 3)$ do valor da remuneração mensal, ofende o critério da razoabilidade que atua, enquanto projeção concretizadora da cláusula do substantive due process of law, como insuperável limitação ao poder normativo do Estado.

Incide o legislador comum em desvio ético-jurídico, quando concede a agentes estatais determinada vantagem pecuniária cuja razão de ser se revela absolutamente destituída de causa. ${ }^{37}$

Percebe-se, claramente, que a inconstitucionalidade teleológica invocada dizia respeito à racionalidade interna da legislação fiscalizada, não se tratando, propriamente, de aplicação da exigência de proporcionalidade. Sob idêntico fundamento, a Suprema Corte suspendeu, em sede de medida cautelar em ação direta de inconstitucionalidade, a execução de lei do Distrito Federal, que determinara a emissão do certificado de conclusão do ensino médio em favor de alunos da terceira série, que, independentemente de frequência às aulas, comprovassem aprovação em vestibular para ingresso em curso de nível superior. Na ocasião, consignou-se na decisão proferida que se evidenciava "a falta de atendimento, por parte do legislador distrital, de padrões mínimos de razoabilidade, a cuja observância estão sujeitos, sem exceção, todos os atos estatais, notadamente aqueles que emanam do Poder Legislativo". ${ }^{38}$

Uma das primeiras decisões do Supremo Tribunal, no âmbito do controle abstrato de normas, fundada na exigência de proporcionalidade em sentido próprio, consistiu no acórdão que, por maioria de votos, julgou inteiramente procedente a Representação ${ }^{39} \mathrm{n}^{\circ}$ 930/DF, declarando inconstitucional lei federal que condicionara o exercício da profissão de corretor de imóveis à comprovação de determinadas condições de capacidade. ${ }^{40}$ Muito embora não se tenha feito referência expressa à

\footnotetext{
37 Acórdão de 19-12-1994; DJ 26-5-1995.

38 ADI $n^{\circ}$ 2.667-MC/DF: j. 19-6-2002; DJ 12-3-2004. Observe-se que o voto emitido pelo Ministro-relator, Celso de Mello, faz referência, indistintamente, às exigências de razoabilidade e de proporcionalidade, a despeito de não se apurar a inconstitucionalidade a partir do exame da relação entre a medida legislativa e normas constitucionais finalísticas, cuidando-se, pois, indubitavelmente, de questão atinente à racionalidade interna do ato controlado.

39 Essa era a denominação da ação direta de inconstitucionalidade na vigência da Emenda no 1/69, à Constituição de 1967: cf. artigo 119, inciso I, alínea $l$.

$40 \mathrm{Na}$ ementa do acórdão, em que atuou como relator o Ministro Rodrigues Alckmin, asseverou-
} 
inadequação da medida, refletindo a acanhada elaboração doutrinária então existente sobre o tema da proporcionalidade, o certo é que o ato legislativo questionado foi visto como contrário à Constituição por estipular requisitos de capacidade que não contribuíam para assegurar a habilitação de profissionais envolvidos na prestação de serviços de maior complexidade técnica.

Alguns anos depois, ao ensejo do julgamento de outra Representação de Inconstitucionalidade ( $\mathrm{n}^{\circ} 1.077 / \mathrm{RJ}$ ), o STF tornou a praticar o controle de proporcionalidade, desta feita constatando o desbalanceamento de lei estadual que estipulara, em montante reputado excessivo, o valor da taxa a ser paga pelas partes em processos judiciais, de modo a afetar o núcleo essencial do princípio da inafastabilidade do controle jurisdicional ${ }^{41}$. Muito embora a ideia de desproporcionalidade entre o valor da taxa judiciária, destinada a cobrir os custos do serviço, e o princípio do acesso à justiça tenha inspirado a decisão, não se chegou a argumentar com a exigência de proporcionalidade e muito menos com o elemento do respeito ao núcleo essencial de normas-princípio de incidência concomitante (proporcionalidade em sentido estrito).

Bem mais consistente, em termos de controle de proporcionalidade, a fundamentação que integrou o voto condutor do acórdão (posterior à Constituição de 88) referente à apreciação de medida cautelar na ação Direta de Inconstitucionalidade $\mathrm{n}^{\mathrm{o}}$ 1.407-2-/DF, conquanto, ao final, se tenha considerado inexistente a cogitada ofensa à Constituição sob esse prisma. ${ }^{42}$

Em manifestação bem mais recente do controle de proporcionalidade (2007), com relação ao elemento da proporcionalidade em sentido estrito, o STF declarou inconstitucional a exigência de depósito ou arrolamento prévio de bens e direitos enquanto condição para o manejo de recurso na esfera administrativo-tributária, porquanto o excesso na legítima estipulação de requisitos ao exercício do direito

se ser "inconstitucional a lei que atenta contra a liberdade consagrada na Constituição Federal, regulamentando e consequentemente restringindo exercício de profissão que não pressupõe condições de capacidade": j. 5-5-1976; DJ 2-9-1977. Em seu voto, o relator se socorreu das noções de razoabilidade e proporcionalidade, que, nesse caso, poderiam mesmo ser utilizadas indistintamente.

41 Acórdão relatado pelo Ministro Moreira Alves: j. 28-3-1984; DJ 28-9-1984.

42 Na espécie, examinava-se a constitucionalidade do caput do artigo 6 $6^{\circ}$, da Lei Federal no 9.100/95, que, em eleições municipais, proíbe coligações partidárias que se restrinjam aos mandatos preenchidos pelo sistema proporcional: Relator Ministro Celso de Mello; j. 7-3-1996; DJ 2411-2000. Dentre outros aspectos concernentes ao tema ora versado, constou da ementa do aresto: "O princípio da proporcionalidade - que extrai a sua justificação dogmática de diversas cláusulas constitucionais, notadamente daquela que veicula a garantia do substantive due process of law - acha-se vocacionado a inibir e a neutralizar os abusos do Poder Público no exercício de suas funções, qualificando-se como parâmetro de aferição da própria constitucionalidade material dos atos estatais." 
constitucional de petição comprimiria o núcleo essencial dessa prerrogativa. ${ }^{43}$ De outra parte, nesse mesmo ano, decidiu a Corte que "não ofende o princípio da proporcionalidade lei que isenta os reconbecidamente pobres do pagamento dos emolumentos devidos pela expedição do registro civil de nascimento e de óbito, bem como a primeira certidão respectiva". ${ }^{44}$

Todavia, a mais cabal e debatida aplicação do princípio da proporcionalidade na jurisprudência do Supremo Tribunal Federal deu-se no julgamento da Ação Direta de Inconstitucionalidade $\mathrm{n}^{\circ}$ 855-2/PR, em que se declarou inconstitucional a Lei $n^{\circ} 10.248 / 93$, do Estado do Paraná, que obrigava os estabelecimentos que comercializassem "Gás Liquefeito de Petróleo - GLP a pesarem, à vista do consumidor, os botijões ou cilindros entregues ou recebidos para substituição, com abatimento proporcional do preço do produto ante a eventual verificação de diferença a menor entre o conteúdo e a quantidade líquida especificada no recipiente”. A declaração de nulidade da legislação estadual impugnada, nos termos expressos na emenda do acórdão proferido por ocasião do julgamento de mérito, assentou-se em dois vícios: inconstitucionalidade formal, "por ofensa à competência privativa da União para legislar sobre o tema” (arts. 22, IV, e 238, da CF); e violação "ao princípio da proporcionalidade e razoabilidade das leis restritivas de direitos". Com efeito, naquela oportunidade, a maioria dos integrantes da Corte divisou inconstitucionalidade finalística por absoluta inadequação da medida restritiva à liberdade de iniciativa econômica, já que laudos técnicos atestavam que não era ela apta a promover a proteção ao consumidor no tocante à precisa correspondência entre o preço pago e a quantidade de produto entregue pelas distribuidoras de gás liquefeito. ${ }^{45}$

43 ADI 1.976-7/DF, da relatoria do Ministro Joaquim Barbosa, que, em seu voto, consignou: "Exigir que o administrado deposite uma determinada quantia ou arrole bens como requisito ao exercício do direito de recorrer equivale, na prática, à supressão desse direito. E justamente aí se encontra a violação ao núcleo essencial do direito de recorrer administrativamente. O exame de proporcionalidade comprova isto." J. 28-3-2007; DJ 18-5-2007.

44 Acórdão proferido no julgamento da Ação Declaratória de Constitucionalidade no 5-2/DF: j. 11-6-2007; DJ 5-10-2007.

45 O julgamento de mérito da ADI no 855 ocorreu em 6-3-2008, porém já em 1-7-1993 o STF, por maioria de votos, houvera deferido pedido de medida cautelar e suspendido a execução da lei questionada. Manifestando-se sobre a fundamentação do veredicto de inconstitucionalidade, aduziu o Ministro Gilmar Mendes, no julgamento de 2008: "Fazendo uma nota sobre isso e também sobre o enquadramento no contexto da idéia de proporcionalidade, eu dizia que o próprio Tribunal, pelo menos em sede de liminar, assentou a inadequação da medida e ainda colocou em dúvida a sua necessidade. Por isso o fundamento não foi, pelo menos em sede de liminar, aquele referente à competência do órgão legislativo estadual, mas tão somente a questão de afronta substancial, isto sim, de excesso de poder legislativo." Veja-se a publicação do julgado no Diário da Justiça de 27-3-2009. 


\section{Avaliação prospectiva}

O uso do denominado controle de proporcionalidade tem se intensificado na jurisprudência brasileira mais recente, porém sem muita precisão, máxime no que concerne ao seu fundamento de legitimidade (genericamente, o próprio princípio da supremacia da Constituição) e à diferenciação para com o controle da razoabilidade interna (formal ou de conteúdo) do ato legislativo. A confusão conceitual se agrava em face das constantes invocações dos "princípios" da proporcionalidade e da razoabilidade fora do campo do controle de constitucionalidade e, portanto, com um sentido profundamente distinto.

Entendo ser absolutamente inexorável que a observância da exigência de proporcionalidade seja cada vez mais cobrada ao legislador pelo Poder Judiciário, no exercício da jurisdição constitucional, por imposição de certas características de nosso constitucionalismo hodierno, de feições social-democráticas, em que a dimensão prospectiva do ideal de justiça social com liberdade se faz acompanhar da inserção de inúmeras normas-fim na Constituição formal, dotada de superioridade hierárquica em relação à legislação ordinária. Ora, a configuração do vício de inconstitucionalidade assume especificidades inequívocas quando são utilizadas como parâmetro normas constitucionais, usualmente principiológicas, inseridas nessa categoria.

$\mathrm{O}$ adensamento da reflexão acadêmica, que longe de se perder em devaneios de elevada abstração teórica, deve se ocupar de emprestar consistência ao controle de proporcionalidade, mormente aquele de natureza abstrata, realizado pelo Supremo Tribunal Federal e pelos Tribunais de Justiça dos Estados e do Distrito Federal, acabará por consolidar uma quarta modalidade de vício de inconstitucionalidade, por mim alcunhado já há mais de 15 (quinze) anos de inconstitucionalidade finalística. ${ }^{46}$ Nesse sentido, seria benéfica a substituição do controle de proporcionalidade, que não se aplica ao exame da razoabilidade interna do ato legislativo, e mesmo do controle de razoabilidade, que ultrapassa os lindes da fiscalização de constitucionalidade da legislação, visto incidir em variadas situações de mera aplicação normativa a fatos concretos, pelo controle de finalidade, de maior compactação teorética, agregando-se ao controle de procedimento, de competência e de substância, sempre tendo por objeto leis e atos normativos.

Não tenho dúvida de que a concentração da competência de controle, com a modelagem definitiva do sistema brasileiro em termos europeus (kelsenianos), contribuiria para o refinamento técnico da jurisprudência na matéria em estudo, dada a maior especialização que acarreta, com reflexos positivos na escolha dos juízes constitucionais e no seu preparo para o exercício da fiscalização de constitucionalidade.

$\overline{46}$ Consulte-se a monografía $\mathbf{A}$ inconstitucionalidade das leis: vício e sanção. São Paulo: Saraiva, 1994, p. 151-155. 
O apuro ora preconizado constitui o antídoto mais eficaz contra a utilização deformada das exigências de proporcionalidade e razoabilidade, da qual se avizinha perigosamente a jurisprudência brasileira, incentivada por construções doutrinárias que pretendem reduzir a dimensões inaceitáveis a discricionariedade legislativa, ${ }^{47}$ abrindo caminho a um devastador ativismo judicial,$^{48}$ de consequências funestas para o Estado Democrático de Direito consagrado pelo Constituinte.

47 Essa deformação pretoriano-acadêmica tem merecido reparos, tão incisivos quanto oportunos, da parte do Ministro do STF, Eros Grau, Professor Titular aposentado da Faculdade de Direito da Universidade de São Paulo, que, no voto proferido na condição de relator do RE no 543.974/ MG, aludiu à "banalização da proporcionalidade". Aliás, a intervenção do Ministro nos debates havidos por ocasião do julgamento da $\mathrm{ADI} \mathrm{n}^{\circ}$ 855/PR merece ser parcialmente transcrita, para melhor apreensão de seu pensamento: “O volume de livros escritos sobre o princípio da proporcionalidade é uma barbaridade. Chega-se verdadeiramente à conclusão de que esta Corte pode fazer o que bem entender a pretexto da proporcionalidade. Ora, isso não é verdadeiro. Se não houver preceito constitucional afrontado pelo texto normativo, efetivamente não nos incumbe afirmar esteja este em conflito com a Constituição."

48 Sobre o ativismo judicial, apresentei tese em concurso para o cargo de Professor Titular, junto ao Departamento de Direito do Estado (Área de Direito Constitucional) da Faculdade de Direito da Universidade de São Paulo, no ano de 2009, trabalho esse na iminência de ser publicado. 


\section{Referência Bibliográficas}

ALEXY, Robert. Teoría de los derechos fundamentales. 2. ed. esp. Trad. e introd. Carlos Bernal Pulido. Madri: Centro de Estudios Politicos y Constitucionales, 2007.

ÁVILA, Humberto. Teoria dos princípios: da definição à aplicação dos princípios jurídicos. 9. ed. São Paulo: Malheiros, 2009.

BARROSO, Luís Roberto. Interpretação e aplicação da Constituição: fundamentos de uma Dogmática constitucional transformadora. 3. ed. São Paulo: Saraiva, 1999.

BRAGA, Valeschka e Silva. Princípios da proporcionalidade \& da razoabilidade.Curitiba: Juruá, 2006.

CANOTILHO, José Joaquim Gomes. Direito constitucional e teoria da Constituição. 7. ed. Coimbra: Almedina, 2003.

CASTRO, Carlos Roberto Siqueira. A Constituição aberta e os direitos fundamentais: ensaios sobre o constitucionalismo pós-moderno e comunitário. Rio de Janeiro: Forense, 2003.

COSTA, Gustavo Carvalho. Ponderação e o princípio da proporcionalidade. Revista da Faculdade de Direito do Sul de Minas, Pouso Alegre, FDSM, 26:131-60, jan./jun. 2008.

DAVID, René. Os grandes sistemas de direito contemporâneo. 2. ed. bras. Trad. Hermínio A. Carvalho. São Paulo: Martins Fontes, 1993.

GRINOVER, Ada Pellegrini. As garantias constitucionais do direito de ação. São Paulo: Revista dos Tribunais, 1973.

GUERRA FILHO, Willis Santiago. Princípio da proporcionalidade e teoria do direito. In: GRAU, Eros Roberto; GUERRA FILHO, Willis Santiago (Orgs). Direito Constitucional: estudos em homenagem a Paulo Bonavides. 1. ed. São Paulo: Malheiros, 2001.

KELSEN, Hans. Jurisdição constitucional. Introd. Sérgio Sérvulo da Cunha. Trad. Alexandre Krug, Eduardo Brandão \& Maria Ermantina Galvão. São Paulo: Martins Fontes, 2003.

MENDES, Gilmar Ferreira; COELHO, Inocêncio Mártires; BRANCO, Paulo Gustavo Gonet. Curso de direito constitucional. São Paulo: Saraiva, 2007.

MILANO, Laure. Contrôle de constitutionnalité et qualité de la loi. Revue du Droit Public. Paris: Librairie Générale de Droit et de Jurisprudence, 3:637-71, maio/jun. 2006.

MIRANDA, Jorge. Manual de direito constitucional. 3. ed. Coimbra: Coimbra Ed., 1996. t. 2.

MOTA, Marcel Moraes. O princípio da proporcionalidade e suas sub-regras. In: TORRENS, Haradja Leite; ALCOFORADO, Mário Sawatani Guedes. (Org.). A expansão do direito: estudos de direito constitucional e filosofia do direito em homenagem a Willis Santiago Guerra Filho (por duas décadas de docência e pesquisas). Rio de Janeiro: Lumen Juris, 287-99, 2004.

MÜLLER, Friedrich. Métodos de trabalho do direito constitucional. 3. ed. Trad. Peter Naumann. Rio de Janeiro: Renovar, 2005.

RAMOS, Elival da Silva. A inconstitucionalidade das leis: vício e sanção. São Paulo: Saraiva, 1994.

. Parâmetros dogmáticos do ativismo judicial em matéria constitucional. São Paulo: Faculdade de Direito da Universidade de São Paulo, 2009. Tese de titularidade.

ROUSSEAU, Dominique. Droit du contentieux constitutionnel. Paris: Montchrestien, 1990.

SANCHÍS, Luis Prieto. Tribunal constitucional y positivismo jurídico. DOXA. Cuadernos de Filosofía del Derecho. Alicante: Universidade de Alicante, 23:194, 2000.

SILVA, Luís Virgílio Afonso da. O proporcional e o razoável. Revista dos Tribunais. São Paulo: Revista dos Tribunais, 798:23-50, abr. 2002.

TÁCITO, Caio. A razoabilidade das leis. Revista de Direito Administrativo. Rio de Janeiro: Fundação Getúlio Vargas, 242:43-9, out./dez. 2005.

TAVARES, André Ramos. Curso de direito constitucional. 3. ed. São Paulo: Saraiva, 2006. 